\title{
PENGARUH STRATEGI PEMASARAN DAN PELAYANAN PERGURUAN TINGGI TERHADAP KEPUASAN PELANGGAN PROGRAM UNGGULAN STRATA SATU (S1) SEKOLAH TINGGI ILMU ADMINISTRASI MANDALA INDONESIA (STIAMI)
}

\author{
Suparman \\ Institut Ilmu Sosial dan Manajemen STIAMI \\ Suparman_sasa@yahoo.co.id
}

\begin{abstract}
Abstrak. Penelitian ini bertujuan mengetahui Pengaruh Strategi Pemasaran dan Kualitas Pelayanan Terhadap Kepuasan Pelanggan/ Mahasiswa. Sampel penelitian sebanyak 32 responden yang diambil dari populasi sebanyak 36 mahasiswa dengan metode Sampling Jenuh. Pengumpulan data menggunakan teknik angket, teknik kuisioner penelitian, dan observasi. Pengolahan data primer menggunakan Metode Analisis Metode Deskriptif Analitik. Dari pembahasan penelitian diperoleh hasil sebagai berikut

Pertama, Tidak Terdapat pengaruh Pemasaran $\left(\mathrm{X}_{1}\right)$ terhadap Kepuasan Pelanggan/Mahasiswa (Y). Nilai signifikasi pada variabel Pemasaran adalah sebesar 0,966 $(<0,05)$ yang berarti tidak ada pengaruh variabel Pemasaran secara parsial terhadap Kepuasan Pelanggan. Sehingga $\mathrm{H}_{0}$ ditolak $\mathrm{H}_{1}$ diterima. Terdapat pengaruh Kualitas Pelayanan $\left(\mathrm{X}_{2}\right)$ yang positif dan signifikan terhadap Kepuasan Pelanggan/Mahasiswa (Y). Nilai signifikasi pada variabel Kualitas Pelayanan adalah sebesar 0,000 $(<0,01)$ yang berarti dengan tingkat keyakinan 99 persen variabel Kualitas Pelayanan secara parsial sangat nyata mempengaruhi Kepuasan Pelanggan. Sehingga $\mathrm{H}_{0}$ diterima $\mathrm{H}_{1}$ ditolak. Terdapat pengaruh positif dan signifikan, Variabel Pemasaran $\left(\mathrm{X}_{1}\right)$ dan Kualitas Pelayanan $\left(\mathrm{X}_{2}\right)$ secara bersama-sama terhadap Kepuasan Pelanggan (mahasiswa) (Y). Melalui uji signifikasi dengan menggunakan distribusi F, diproleh F hitung diperoleh Signifikansi sebesar 0,000 $(<0,05)$. Ini berarti $\mathrm{H}_{0}$ diterima atau $\mathrm{H}_{1}$ ditolak. Dan besarnya nilai Koefisien Determinasi yang diperoleh dengan perhitungan SPSS adalah sebesar 0.718. Hal ini menunjukkan bahwa 71,8\% Nilai ini menunjukkan bahwa variasi total pengaruh seluruh variabel bebas terhadap variabel Kualitas Pelanggan/Mahasiswa. Pengaruh variabel lain diluar variabel yang diteliti adalah sebesar 28,2 persen.
\end{abstract}

Kedua, Strategi Pemasaran dan Kualitas Pelayanan baik secara individual maupun secara bersamasama berpengaruh terhadap kepuasan pelanggan/mahasiswa.

Kata Kunci : Strategi Pemasaran, Kualitas Pelayanan dan Kepuasan Pelanggan

Abstract. This study aims to determine the Effects of Marketing Strategies and Customer Satisfaction Quality Of Service / Student. Samples are 32 respondents drawn from a population of 36 students with Saturated sampling method. Data collection using questionnaire techniques, engineering research questionnaires, and observation. Processing of primary data using Analytical Methods Descriptive Analysis Method. From the discussion following results were obtained:

First, There is the influence of Marketing (X1) on Customer Satisfaction / Student (Y) . Marketing significant value in the variable is equal to $0.966(<0.05)$ which means that there is no influence of marketing variables partially on Customer Satisfaction. So HO is rejected HI is accepted. There is the influence of Quality of Service (X2) are positive and significant impact on Customer Satisfaction / Student $(Y)$. The value of significance in the variable quality of service is equal to $0.000(<0.01)$, which means with a confidence level of 99 percent variable partial Service Quality Customer Satisfaction is very real influence. So $\mathrm{HO} \mathrm{HI}$ is rejected. There is positive and significant, Marketing Variables (X1) and Quality of Service (X2) jointly against Employee Morale (Y). Through the significance test using the F distribution, obtained Significance calculated $F$ of 0.000 ( $<0.05)$. This means that HO is accepted or rejected H1. And the value of the coefficient of determination obtained with SPSS calculation amounted to 0.718. This indicates that $71.8 \%$ of this value indicates that the total variation influences all independent variables to variable Quality 


\section{ISSN 1411-0830}

Customer / Students. The influence of other variables beyond the variables studied was 28.2 percent. variables beyond the variables studied was 28.2 percent .

Secondly, Strategy Marketing and Service Quality, both individually and jointly influence on customer satisfaction / student.

Key Word : Marketing Strategy, Service Quality and Customer Satisfaction

\section{PENDAHULUAN}

Perkembangan zaman yang begitu cepat menyebabkan dunia pendidikan menghadapi tantangan yang amat berat, terutama dalam upaya menyiapkan sumberdaya manusia (SDM) yang berkualitas, yang mampu bersaing di era global. Tantangan tersebut semakin kompleks karena semakin pesatnya perkembangan ilmu pengetahuan dan teknologi, percepatan liberalisasi ekonomi, dan membanjirnya informasi. Derasnya arus informasi menjadikan masyarakat lebih kritis dalam berfikir, bertindak, dan dalam memandang sesuatu persoalan.

Sekolah Tinggi Ilmu Administrasi Mandala Indonesia (STIAMI) adalah salah satu lembaga pendidikan tinggi yang menyelenggarakan Pendidikan Program Sarjana, Diploma dan Pascasarjana Ilmu Administrasi. Dalam fungsinya sebagai Pendidikan Tinggi, STIAMI dengan seluruh jajarannya mempunyai tanggung jawab dalam menyiapkan sebagian besar lulusannya untuk menjadi Ahli pajak dan Bisnis yang berkualitas, yaitu profesional dan kompeten, STIAMI telah melakukan berbagai upaya baik berkaitan dengan kualitas masukan, perbaikan kurikulum, pemutakhiran silabi, pengembangan sumberdaya manusia, maupun berbagai kegiatan pengembangan lainnya.

Menyadari keadaan tersebut STIAMI menyediakan suatu Program Unggulan untuk mereka yang ingin menjadi unggul dalam bidang Bisnis dan Pajak, Sistem perkuliahan kurikulum program unggulan menggunakan kurikulum revolusiner yang didesain khusus untuk mempersiapkan mahasiswa siap kerja dan berwirausaha dengan kemampuan penguasaan ilmu pajak dan bisnis membuat standar kemampuan lulusan mampu mengembangkan pengetahuan dan pemahaman di bidangnya. Untuk dapat memberikan bekal yang memadai agar lulusannya unggul, berkualitas dan kompeten dibutuhkan adanya pelayanan akademik yang juga berkualitas. Pelayanan akademik secara sistemik diberikan oleh STIAMI melalui Jurusan/Program Studi, Bagian Administrasi Akademik, Bagian Keuangan dan sebagainya. Pelayanan akademik merupakan salah satu jenis pelayanan yang diberikan oleh lembaga sebagai pihak yang melayani kepada mahasiswa. Sekurang-kurangnya ada tiga jenis pelayanan diberikan kepada mahasiswa, yaitu pelayanan akademik atau kurikuler, administrasi dan ekstra kurikuler. Persaingan industri yang semakin kompetitif menuntut setiap perguruan tinggi agar mampu mempertahankan keberadaannya.

Sebagai salah satu Perguruan Tinggi Swasta diIndonesia, STIAMI dituntut meningkatkan mutu layanan dan mutu akademik agar mampu bersaing dengan perguruan tinggi lainnya. STIAMI merupakan perguruan tinggi yang didirikan pada tahun 1983, yang memiliki segmen pasar lulusan SMU/K dan Diploma, baik dari STIAMI sendiri maupun dari perguruan tinggi lainnya. Dilingkungan STIAMI terdapat program penyelenggaraan khusus lainnya yang bersaing memperebutkan pasar tersebut. Disamping itu banyak perguruan tinggi lain yang menawarkan program penyelenggaraan khusus baik dari perguruan tinggi negeri maupun perguruan tinggi swasta. Persaingan yang kian kompetitif antara Perguruan Tinggi Negeri (PTN) maupun Perguruan Tinggi Swasta (PTS) dalam merebutkan segmen pasar, menuntut STIAMI berupaya meningkatkan mutu layanan dalam menjamin mutu lulusan. Mutu lulusan harus menjadi fokus perhatian dalam membangun keunggulan bersaing dengan perguruan tinggi lainnya. Daya saing sebuah perguruan tinggi sangat ditentukan oleh mutu lulusannya.

Sejak tahun 2008/2009 sampai dengan tahun akademik 2011/2012 dari tahun ke tahun jumlah minat mahasiswa untuk 
Suparman, Pengaruh Strategi Pemasaran Dan Pelayanan Perguruan Tinggi Terhadap Kepuasan...

memasuki kelas unggulan trendnya semakin menurun, disisi lain terdapat fenomena menurunnya kinerja akademik kelas unggulan, hal ini di tunjukkan oleh ketatnya persaingan dalam industri jasa pendidikan mengharuskan STIAMI untuk menjaga kualitasnya dalam mengetahui apa kebutuhan dan keinginan pelanggan. Hal ini dimaksudkan agar STIAMI memiliki kekuatan bersaing yang baik dalam menarik perhatian pelanggan maupun mempertahankan kesetiaan dan kepercayaan pelanggan dengan meningkatkan mutu layanan dan mutu lulusan. STIAMI sangat bergantung pada pelanggan, Manajemen STIAMI harus menjadikan pelanggan sebagai prioritas utama. Oleh karena itu, perlu diketahui kualitas pelayanan produk jasa yang dibutuhkan dan diinginkan oleh pelanggan pada industri jasa pendidikan. Selain itu, perusahaan juga perlu mengetahui pengaruh pelayanan yang diberikan terhadap prestasi akademik mahasiswa.

Atas dasar itulah, maka penulis tertarik untuk meneliti (1) Seberapa besar pengaruh strategi pemasaran terhadap jumlah mahasiswa program unggulan strata satu (S1) STIAMI ; (2) Seberapa besar pengaruh kualitas pelayanan terhadap jumlah mahasiswa program unggulan strata satu (S1) STIAMI ; (3) Seberapa besar pengaruh strategi pemasaran dan kualitas pelayanan secara bersama sama terhadap kepuasan mahasiswa program unggulan strata satu (S1) STIAMI.

\section{KAJIAN LITERATUR}

\section{Strategi Pemasaran}

Menurut Philip Kotler (2004:81), strategi pemasaran adalah pola pikir pemasaran yang akan digunakan untuk mencapai tujuan pemasarannya.Strategi pemasaran berisi strategi spesifik untuk pasar sasaran, penetapan posisi, bauran pemasaran dan besarnya pengeluaran pemasaran." Sedangkan menurut Tjiptono (2002:6), strategi pemasaran adalah alat fundamental yang direncanakan untuk mencapai perusahaandengan

mengembangkan keunggulan bersaing yang berkesinambungan melalui pasar yang dimasuki dan program pemasaran yang digunakan untuk melayani pasar"

\section{Pengertian Pemasaran}

Menurut Philip Kotler (2000:9) pemasaran adalah :'Suatu proses sosial yang didalamnya terdapat individu dan kelompok mendapatkan apa yang mereka butuhkan dan inginkan dengan menciptakan, menawarkan dan secara bebas mempertukarkan produk yang bernilai dengan pihak lain”. Sedangkan menurut Freddy Rangkuti (2004 : 11) Pemasaran adalah : "suatu proses kegiatan yang dipengaruhi oleh berbagai faktor sosial, budaya, politik, ekonomi, dan manajerial. Akibat dari pengaruh berbagai faktor tersebut adalah masing-masing individu maupun kelompok mendapatkan kebutuhan dan keinginan dengan menciptakan, menawarkan, dan menukarkan produk yang memiliki nilai komoditas."

\section{Pengertian Bauran Pemasaran}

Menurut Philip Kotler (2000:18), bauran pemasaran adalah seperangkat alat pemasaran yang digunakan perusahaan untuk terus menerus mencapai tujuan pemasarannya dipasar sasaran.

\section{Konsep Penjualan (selling concept)}

Berkeyakinan bahwa konsumen tidak akan tertarik untuk membeli produk dalam jumlah banyak, jika mereka tidak diyakinkan dan bahkan bila perlu dibujuk. Penganut konsep ini akan berkonsekuensi pada usahausaha promosi dan penjualan unsought goods (seperti asuransi, ensiklopedia dan batu nisan), pemasaran nirlaba (penggalangan dana, partai politik dan universal) dan situasi overcapacity (penawaran jauh melampaui permintaan).

\section{Konsep Pemasaran (marketing concept)}

Kunci untuk mewujudkan tujuan organisasi dalam menciptakan, memberikan, dan mengkomunikasikan nilai pelanggan (customer value) kepada pasar sasarannya secara efektif daandingkan pesaing. Konsep 
ini bertumpu pada empat pilar utama : pasar sasaran, kebutuhan pelanggan, pemasaran terintegrasi dan profibilitas. Pasar sasaran adalah pelanggan yang dipilih untuk dilayani dengan program pemasaran khusus bagi mereka

\section{Konsep Pemasaran Masyarakat}

Konsep ini menegaskan bahwa tugas organisasi menentukan kebutuhan, keinginan, dan minat dari pasar sasaran dan memberikan kepuasan yang diinginkan secara lebih efektif dan efisien dibandingkan pesaing dengan tetap memelihara atau meningkatkan kesejahteraan masyarakat atau konsumen. Mereka harus menyeimbangkan dan mengatur kriteria laba perusahaan, pemuasan keinginan konsumen dan kepentingan publik yang sering berkonflik. Konsep ini menekankan tidak hanya sekedar dapat memuaskan pelanggan dan profit (laba), tetapi bagaimana perusahaan dapat memberikan jaminan sosial kepada karyawan dan masyarakat atas pencemaran lingkungan. Keberhasilan pemasaran sangat ditentukan pula oleh kemampuan organisasi dalam membedakan lima jenis kebutuhan, yaitu :

1. Stated Needs (contohnya, konsumen membutuhkan biaya kuliah yang tidak mahal).

2. Real Needs (contohnya, konsumen membutuhkan kuliah yang biaya operasionalnya yang murah).

3. Unstated Needs (contohnya, konsumen mengharapkan layanan prima dari perguruan tinggi).

4. Delight Needs (contohnya, konsumen berharap bahwa Perguruan Tinggi memberikan pula bonus berupa potongan biaya kuliah.

5. Secret Needs (contohnya, konsumen ingin dipandang teman-temannya sebagai konsumen yang cerdas dalam memilih produk).

Marketing mix merupakan alat bagi marketer yang terdiri dari berbagai elemen auatu program pemasaran yang perlu dipertimbangkan agar implementasi strategi pemasaran dan posotioning yang ditetapkan dapat berjalan sukses. Marketing mix pada produk barang yang kita kenal selama ini berbeda dengan marketing mix untuk produk jasa. Hal ini terkait dengan perbedaan karakteristik jasa dan barang. Marketing mix produk barang mencakup $4 \mathrm{P}$ : product, price, place dan promotion. Sedangkan untuk jasa keempat hal tersebut masih dirasa kurang mencukupi. Para ahli pemasaran menambahkan tiga unsur lagi : pople, process, dan Phsical Evidance

\section{Product ( Produk )}

Produk adalah merupakan keseluruhan konsep objek atau proses yang memberikan sejumlah nilai manfaat kepada konsumen. Atribut-atribut produk adalah sesuatu yang melengkapi manfaat utama produk sehingga mampu lebih memuaskan konsumen”. Atribut produk meliputi merek (brand), pembungkusan (packaging), label, garansi atau jaminan (warranty) dan produk tambahan (service). Atribut dapat dipandang secara obyektif (fisik produk) maupun secarasubyektif (Teguh Budiarto (1993:68)

\section{Pricing ( Harga )}

Menurut Kotler dan Amstrong (2008:1), harga merupakan sejumlah uang yang dibebankan atas suatu produk atau jasa, atas jumlah dari nilai yang ditukar konsumen atas manfaat-manfaat karena memiliki atau menggunakan produk atau jasa tersebut".

\section{Place ( Tempat)}

Tempat dalam service merupakan gabungan antara lokasi dan keputusan atas saluran distribusi, dalam hal ini berhubungan dengan bagaimana cara penyampaian jasa kepada konsumen dan dimana lokasi yang strategis. Penyampaian jasa juga dapat melalui organisasi maupun orang lain diantaranya ada tiga pihak yang terlibat yaitu service provider, intermediaries, customers.

\section{Promotion( Promosi )}

Yang perlu diperhatikan dalam promosi adalah pemilihan bauran pemasaran terdiri dari :(a) Advertaising ; (b) Personel Selling ; (c) Sales Promotion (d) Public Relation; (e)Word Of Mount dan (f) Direct Mail 
Suparman, Pengaruh Strategi Pemasaran Dan Pelayanan Perguruan Tinggi Terhadap Kepuasan...

\section{People (Orang);}

People (Orang) adalah orang-orang yang terlibat langsung dalam menjalankan segala aktifitas perusahaan, dan merupakan faktor yang memegang peranan penting bagi semua organisasi. Dalam perusahaan jasa unsur people ini bukan hanya memainkan peranan penting dalam bidang produksi atau operasional saja, tetapi juga dalam melakukan hubungan kontak langsung dengan konsum

\section{Process (Proses)}

Proses merupakan gabungan semua aktivitas, umumnya terdiri dari prosedur, jadwal pekerjaan, mekanisme, aktvitas dan hal-hal rutin dimana jasa dihasilkan dan disampaikan ke konsumen.

\section{Phsical Evidance (Bukti Fisik)}

Bentuk fisik merupakan lingkungan dimana jasa service diberikan termasuk perlengkapan nyata yang dapat membantu dalam berkomunikasi dan memperlancar jasa service itu sendri, contonya gedung, peralatan dan lain-lain.

\section{Pelayanan}

Layanan adalah suatu kegiatan atau rangkaian kegiatan lebih atau kurang di alam nyata yang biasanya, tetapi tidak harus, berlangsung dalam interaksi antara pelanggan dan layanan karyawan dan / atau sumber daya fisik atau sistem yang baik dan / atau penyedia layanan, yang disediakan sebagai solusi untuk masalah pelanggan (Gronroos, 1990)).

Untuk memberikan suatu pelayanan yang terbaik bagi pelanggan ada 4 macam pelayanan yang harus dikelola secara bersama-sama untuk mendapatkan hasil yang maksimal, 4 macam pelayanan menurut Herman Kertajaya (1994:123) adalah:

a. Pelayanan sebagai produk yang dijual.

Dalam hal ini seorang marketing harus mampu membuat pelayanan yang dijual sebagai produk yang terdiri dari beberapa elemen seperti: features, quality dan style yang harus diberikan dalam pelayanan yang akan dijual.

b. Before sales service yaitu pelayanan yang diberikan sebelum penjualan berlangsung. c. In-sales services yaitu pelayanan yang diberikan pada waktu penjualan sedang berlangsung.

d. After sales services yaitu pelayanan yang diberikan setelah penjualan berlangsung.

\section{Kualitas Pelayanan}

Menurut Zeithaml (1990:176) kualitas pelayanan pada dasarnya merupakan kesesuaian anatara pelayanan yang diterima (perceived service) dibandingkan dengan pelayanan yang diharapkan (expected service).

Menurut Parasuraman Zeithaml, dan Berry (2001:70), terdapat lima dimensi SERVQUALsebagai berikut

a) Tangibles, atau bukti fisik yaitu kemampuan suatu perusahaan dalammenunjukkan eksistensinya kepada pihak eksternal. Penampilan dan kemampuan sarana dan prasarana fisik perusahaan dan keadaan lingkungan sekitarnya adalah bukti nyata dari pelayanan yang diberikan oleh pemberi jasa. Yang meliputi fasilitas fisik (gedung, gudang, dan lain sebagainya), perlengkapan dan peralatan yang dipergunakan (teknologi), serta penampilan pegawainya.

b) Reliability, atau kehandalan yaitu kemampuan perusahaan untuk memberikan pelayanan sesuai yang dijanjikan secara akurat dan terpercaya. Kinerja harus sesuai dengan harapan pelanggan yang berarti ketepatan waktu, pelayanan yang sama, untuk semua pelanggan tanpa kesalahan, sikap yang simpatik, dan dengan akurasi yang tinggi.

c) Responsiveness, atau ketanggapan yaitu suatu kemampuan untuk membantu dan memberi pelayanan yang cepat (responsif) dan tepat kepada pelanggan, dengan penyampaian informasi yang jelas. Membiarkan konsumen menunggu tanpa adanya suatu alasan yang jelas menyebabkan persepsi yang negatif dalam pelayanan.

d) Assurance, atau jaminan dan kepastian yaitu pengetahuan, kesopansantunan, dan kemampuan para pegawai perusahaan 
untuk menumbuhkan rasa percaya para pelanggan kepada perusahaan. Terdiri dari beberapa komponen antara lain komunikasi (communication), kredibilitas (credibility), keamanan (security), kompetensi (competence), dan sopan santun (courtesy).

e) Emphaty, yaitu memberikan perhatian yang tulus dan bersifat individual atau pribadi yang diberikan kepada para pelanggan dengan berupayamemahami keinginan konsumen. Dimana suatu perusahaan diharapkan memiliki pengertian dan pengetahuan tentang pelanggan, memahami kebutuhan pelanggan secara spesifik, serta memiliki waktu pengoperasian yang nyaman bagi pelanggan.

\section{Kepuasan}

Menurut pendapat Day seperti yang dikutip oleh Tjiptono dan Diana (1995:102), kepuasan adalah respons terhadap evaluasi ketidaksesuain yang dirasakan antara harapan sebelumnya dengan kinerja aktual produk yang dirasakan setelah pemakaiannya”. Sedangkan menurut Hulley yang dikutip oleh Supranto (1997:233) definisi kepuasan adalah: "tingkat perasaan seseorang setelah membandingkan kinerja yang dirasakannya dengan harapannya".

Penilaian kepuasan atau ketidakpuasan konsumen terhadap produk atau jasa yang telah dikonsumsinya dianyatakan oleh Oliver (1997:105) dibagi tiga yaitu:

a. Positive Disconfirmation

b) Merupakan reaksi konsumen bila penampilan produk atau jasa yang dikonsumsikan lebih dari yang diharapkan.

a. Zero Disconfirmation

c) Adalah reaksi bila penampilan produk atau jasa yang dikonsumsi sesuai dengan atau sama dengan yang diharapkan.

a. Negative Disconfirmation

d) Adalah reaksi konsumen jika penampilan produk atau jasa yang dikonsumsinya lebih rendah dari yang diharapkannya.

\section{Kepuasan Pelanggan/Mahasiswa}

Menurut Tampubolon (2001:157)

kebutuhan ialah segala sesuatu yang diperlukan manusia untuk kehidupannya. Apabila dihubungkan dengan pendapat Maslow dipandang dari sudut pendidikan, kebutuhan mahasiswa adalah terkait dengan the self actualization needs.

Menurut Tampubolon (2001:88) berkaitan dengan kemampuan yang diharapkan tumbuh dan berkembang dalam diri mahasiswa berkenaan dengan bidang studinya meliputi tiga aspek yaitu:
a. Peningkatan dan pengembangan kecerdasan intelektual (KI)
b. Peningkatan dan pengembangan kecerdasan emosional (KE)
c. Peningkatan dan pengembangan motoris (KM)

\section{Dimensi Kepuasan}

Menurut Zeithaml dan Bitner (2003) bahwa kepuasan adalah konsep yang jauh lebih luas dari hanya sekedar penilaian pelayanan, tatapi juga dipengaruhi oleh faktor-faktor lain. Faktor-faktor tersebut adalah kualitas pelayanan, kualitas produk, harga, factor situasi dan factor pribadi.

Sedangkan Kotler seperti yang dikutip Rangkuti(2002), kepuasan pelanggan merupakan perasaan senang atau kecewa seseorang sebagai hasil dari perbandingan antara prestasi atau produk yang dirasakan dan yang diharapkannya. Dengan demikian dimensi dari kepuasan dapat disimpulkan sebagai berikut: (1) Tidak adanya keluhan yang dirasakan oleh pelanggan, (2) Tidak adanya kesalahan atau sedikit kesalahan, dan (3) perbaikan yang terus menerus. Semua dimensi inilah yang dapat menjadikan pelanggan dalam hal ini mahasiswa puas atas pelayanan dan kompetensi dosen.

\section{Hipotesis}

Menurut Good dan Scates dalam Natsir (1999: 182), hipotesis adalah sebuah taksiran atau referensi yang dirumuskan serta diterima untuk sementara yang dapat menerangkan fakta-fakta yang diamati dan digunakan sebagai petunjuk untuk langkah 
Suparman, Pengaruh Strategi Pemasaran Dan Pelayanan Perguruan Tinggi Terhadap Kepuasan...

penelitian selanjutnya. Jadi dapat disimpulkan bahwa hipotesis merupakan jawaban atau dugaan sementara dari masalah yang diteliti. Dengan demikian maka hipotesis pada penelitian ini dapat dirumuskan sebagai berikut:

1. $\mathrm{H}_{0}=$ Strategi Pemasaran STIAMI yang ditempuh/diterapkan memberikan pengaruh terhadap kepuasan pelanggan/mahasiswa.

$\mathrm{H}_{1}=$ Strategi Pemasaran STIAMI yang ditempuh/diterapkan tidak memberikan pengaruh terhadap kepuasan pelanggan/ mahasiswa.

\section{Kerangka Konseptual dan Model Penelitian}

2. $\mathrm{H}_{0}=$ Kualitas pelayanan STIAMI yang diterapkan memberikan pengaruh terhadap kepuasan pelanggan.

$\mathrm{H}_{1}=$ Kualitas pelayanan STIAMI yang diterapkan tidak memberikan pengaruh terhadap kepuasan pelanggan.

3. $\mathrm{H}_{0}=$ Strategi pemasaran dan Kualitas pelayanan yang ditempuh/diterapkan memberikan pengaruh terhadap kepuasan pelanggan/mahasiswa.

$\mathrm{H}_{1}=$ Strategi pemasaran dan Kualitas pelayanan yang ditempuh/diterapkan tidak memberikan pengaruh terhadap kepuasan pelanggan/mahasiswa.

Kerangka konseptual dan model penelitian ini dapat digambarkan sebagai berikut:

\section{Gambar 1. Model Penelitian}

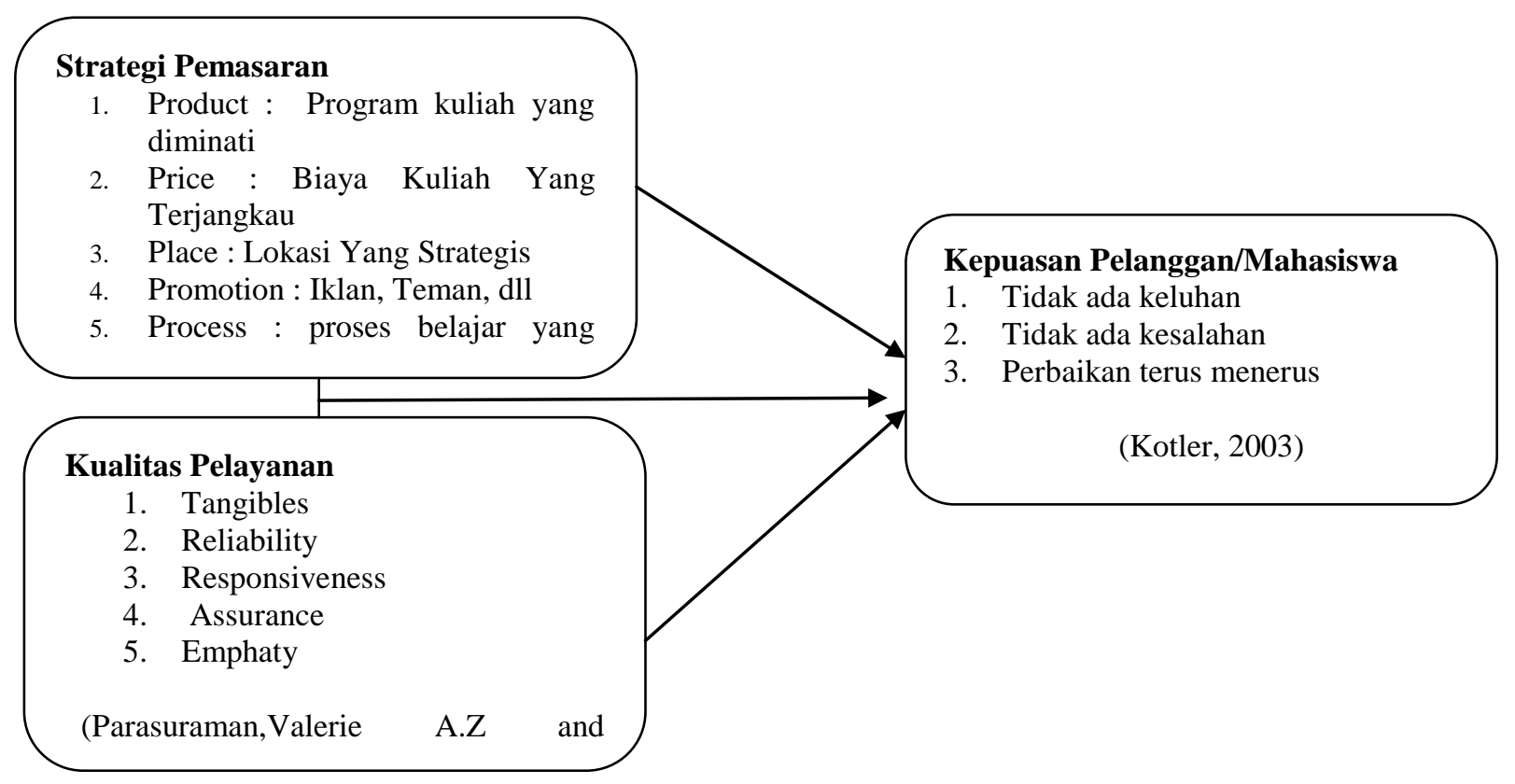

\section{METODE PENELITIAN}

Dalam penelitian ini penulis menerapkan dimensi-dimensi berdasarkan yang diutarakan oleh Neuman. Merujuk pada Neuman (2006:21-39) dimensi Penelitian adalah:

\section{Dimensi Tujuan Penggunaan}

Dilihat dari tujuannya, dimensi penelitian ini bersifat terapan.

\section{Dimensi Tujuan Penjelasan}

Berdasarkan dimensi tujuan penjelasan, tesis ini menerapkan dimensi penjelasan atau deskriptif. 


\section{Dimensi Waktu}

Dimensi waktu yang sesuai dengan penelitian ini adalah dimensi cross-sectional 'satu periode tertentu dalam satuwaktu yakni penelitian tesis ini meliputi beberapa bulan dalam satu tahun yakni dari Maret 2013 sampai dengan Januari 2014.

\section{Dimensi Pengumpulan Data}

Dimensi pengumpulan data dalam penelitian ini adalah dimensi survey karena terdapat populasi dari objek penelitian. Tabel 3.1

\section{Jenis Data}

Dalam penelitian ini, jenis data bersifat kuantitatif. Menurut Mudrajat Kuncoro (2003), data kuantitatif adalah data yang diukur dalam suatu skala numerik (angka)

Begitu juga data yang diukur dalam penelitian ini menggunakan skala Likert. Skala Likert digunakan untuk mengukur sikap, pendapat, dan persepsi seseorang atau sekelompok orang dengan fenomena social.Skala-skala ini nantinya dijumlahkan untuk mendapatkan gambaran mengenai perilaku.

\section{Teknik Pengumpulan Data}

Teknik pengumpulan data yang dilakukan dalam penelitian ini adalah berbentuk (1) Kuesioner dan (2) Observasi

\section{Populasi}

Menurut Babbie dalam Sukardi (2007:53) "Populasi tidak lain adalah elemen penelitian yang hidup dan tinggal bersamasama dan secara teoritis menjadi target hasil penelitian. Berdasarkan pendapat tersebut, maka populasi dalam penelitian ini adalah mahasiswa S1 kelas unggulan Sekolah Tinggi Ilmu Administrasi Mandala Indonesia Jakarta.Jumlah populasi yakni mahasiswa unggulan STIAMI angkatan tahun 2010 adalah 20 orang dan angkatan 2011 sebanyak 16 orang sehingga jumlah responden 36 orang. Berdasarkan data dari Bidang Data dan Informasi STIAMI.

\section{Sampel}

Menurut Suharsimi Arikunto (1993: 107) jika jumlah populasinya kurang dari 100 , lebih baik semua elemen diambil sebagai sampel sehingga penelitiannya merupakan penelitian populasi atau sensus. Selanjutnya, jika jumlah populasinya besar maka jumlah sampel dapat diambil antara 10 s.d. $15 \%$ atau 20 s.d. $25 \%$ atau lebih. Untuk penelitian yang risikonya besar, tentu saja jika jumlah sampel lebih besar, hasilnya akan lebih baik. Berdasarkan pendapat diatas penulis mengambil $100 \%$ dari jumlah populasi mahasiswa unggulan STIAMI Jakarta.

\section{Teknik Pengambilan Sampel}

Dalam penelitian ini, teknik pengambilan sampel adalah probability sampling yaitu: simple random sampling dimana pengambilan sampel dilakukan secara acak untuk memberikan peluang yang sama pada setiap anggota populasi untuk dipilih menjadi anggota sampel.

\section{Teknik Analisis Data}

Untuk mendapatkan data yang akurat diperlukan alat ukur yang akurat pula. Untuk itu perlu melakukan pengujian terhadap instrument (alat ukur) yang akan digunakan. Kegiatan pengujian instrument penelitian meliputi dua hal, yaitu pengujian validitas dan reliabilitas. Pentingnya pengujian validitas dan reliabilitas karena proses pengukuran cenderung keliru.

\section{Pengujian Validitas}

Suatu instrument pengukuran dikatakan valid jika instrument tersebut dapat mengukur sesuatu dengan tepat apa yang hendak diukur. Ada dua jenis validitas untuk instrumen penelitian, yaitu validitas logis (logical validity)dan validitas empiris (empirical validity).(Suharsirni Arikunto, 1993:219).

\section{Pengujian Reliabilitas}

Suatu instrument pengukuran dikatakan reliable jika pengukurannya dengan tujuan mengetahui konsistensi dari instrument sebagai alat ukur, sehinggahasil pengukuran dapat dipercaya. Hasil pengukuran dapat 
Suparman, Pengaruh Strategi Pemasaran Dan Pelayanan Perguruan Tinggi Terhadap Kepuasan...

dipercaya hanya apabila dalam beberapa kali pelaksanaan pengukuran terhadap kelompok subjek yang sama (homogen) diperoleh hasil yang relatif sama, selama aspek yang diukur dalam diri subjek memang belum berubah.

Tabel 1. Operasionalisasi Variabel

\begin{tabular}{|c|c|c|c|}
\hline VARIABEL & DIMENSI & INDIKATOR & $\begin{array}{l}\text { NO. } \\
\text { ITEM }\end{array}$ \\
\hline $\begin{array}{l}\text { Strategi Pemasaran (X1) } \\
\text { (Kotler) dalam buku } \\
\text { David Wijaya }(2012: 77)\end{array}$ & $\begin{array}{l}\text { (1)Product } \\
\text { (Produk) } \\
\\
\text { (2) Pricing ( } \\
\text { Harga ) } \\
\\
\\
\text { (3)Place } \\
\text { Tempat) } \\
\\
\text { (4)Promotio } \\
n \\
\text { ( Promosi ) } \\
\\
\text { (7)Phsical } \\
\text { Evidance } \\
\text { (Bukti }\end{array}$ & $\begin{array}{l}\text { Mendapat fasilitas lebih } \\
\text { Tambahan pendalaman materi } \\
\text { 3. Magang di perusahaan } \\
\text { 4. Mendapatkan jaminan pekerjaan } \\
\text { 5. di serap di dunia kerja } \\
\text { 6. beberapa Perusahaan merekruit lulusan ini } \\
\text { Terjangkau } \\
\text { Mahasiswa mampu bayar } \\
\text { Bisa dicicil } \\
\text { Fleksibel tidak dikenakan denda } \\
\text { Beasiswa khusus dgn syarat } \\
\text { Beasiswa berprestasi } \\
\text { Berada di pinggir jalan raya } \\
\text { Terlihat dari berbagai penjuru } \\
\text { Dekat dengan pusat Pemerintahan } \\
\text { Berada di pusat perdagangan } \\
\text { Sarana transportasi menjangkau } \\
\text { Mudah menggunakan transportasi umum } \\
\text { 1. Mahasiswa mengenal dari Televisi } \\
\text { 2. Iklan televisi } \\
\text { 3. Informasi melalui Internet } \\
\text { 4. Iklan mendunia dengan internet } \\
\text { 5. Informasi dari Teman dan Keluarga } \\
\text { 6. Rekomendasi } \\
\text { 1. Pengetahuan staf pelayanan } \\
\text { 2. Kemampuan dosen Ajar } \\
\text { 3. Dosen/staf melayani sepenuh hati } \\
\text { 4. Bangga sebagai karyawan } \\
\text { 5. Ramah dan siap membantu } \\
\text { 6. Jujur dan berkelakuan baik } \\
\text { Layanan yg cepat dan tepat waktu } \\
\text { Adanya target penyelesaian } \\
\text { Mudah mengakses informasi, } \\
\text { Mudah dan terlayani, aktvitas dan hal-hal rutin } \\
\text { Area Gedung rapid dan tertata } \\
\text { Bangunan kokoh dan kuat } \\
\text { Fasilitas bersih dan nyaman } \\
\text { Gedung terus diperbaiki dan berkembang } \\
\text { (a) }\end{array}$ & $\begin{array}{l}1,2,3,4,5,6,7 \\
, 8 \\
1,2,3,4,5,6\end{array}$ \\
\hline
\end{tabular}




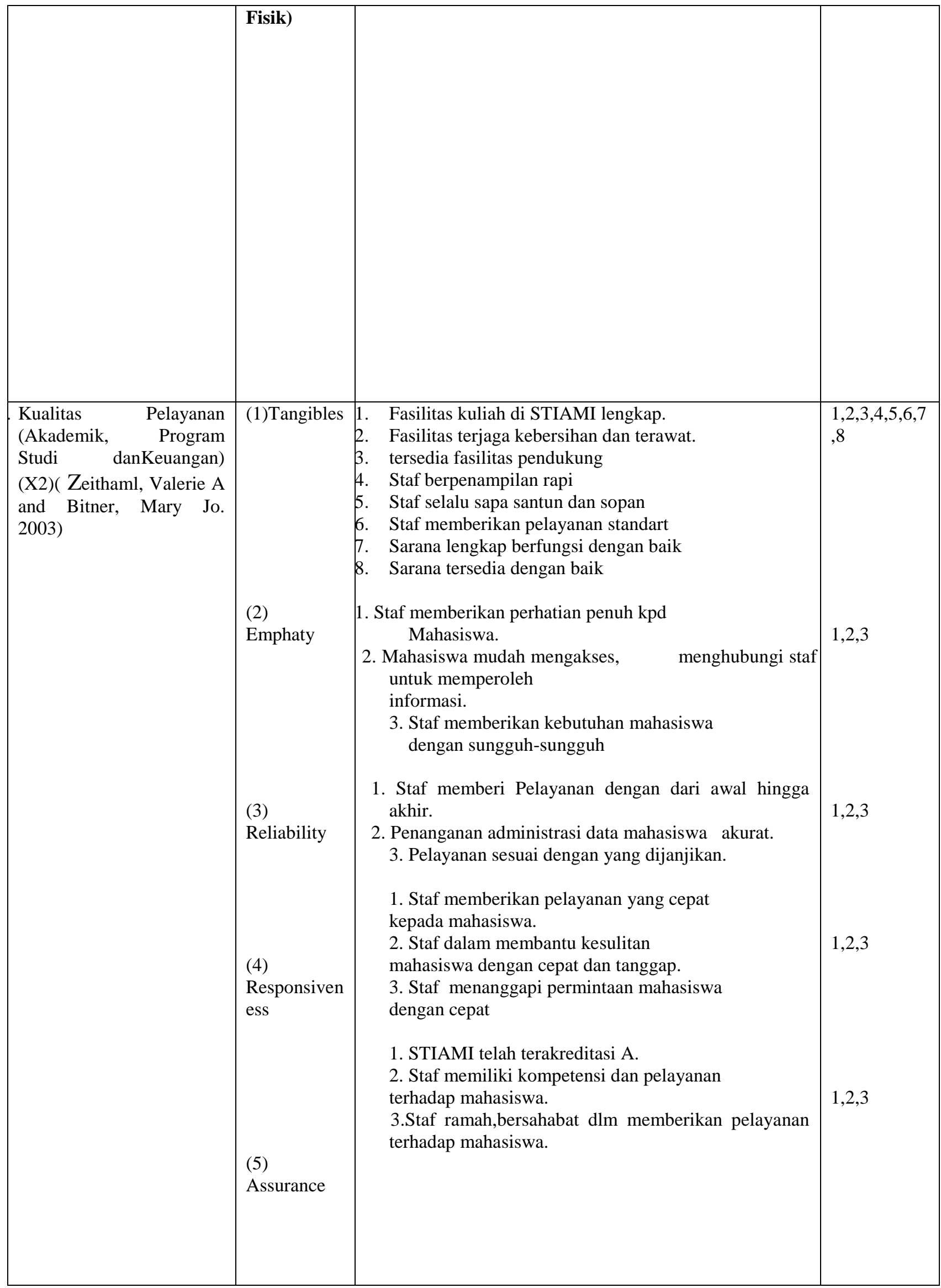


Suparman, Pengaruh Strategi Pemasaran Dan Pelayanan Perguruan Tinggi Terhadap Kepuasan...

\begin{tabular}{|c|c|c|c|}
\hline $\begin{array}{l}\text { Kepuasan Mahasiswa } \\
\text { (Kelas Unggulan STIAMI)(Y) } \\
(\text { Kotler,2003) }\end{array}$ & $\begin{array}{l}\text { (1) Tidak } \\
\text { ada } \\
\text { Keluhan } \\
\text { (2) Tidak } \\
\text { ada } \\
\text { kesalahan } \\
\\
\text { (3) } \\
\text { Perbaikan } \\
\text { terus } \\
\text { Menerus }\end{array}$ & $\begin{array}{l}\text { 1.Pengetahuan yg lengkap dan sempurna dari Dosen. } \\
\text { 2.Kualitas pelayanan yg prima dari staf } \\
\text { Akademik,Keuangan dan Prodi } \\
\text { 3.Sedikit Complain } \\
\text { 1.Sedikit kesalahan yang dilakukan staf } \\
\text { Akademik,Keuangan dan Prodi } \\
\text { 2. Informasi yang lengkap dan akurat dari bag. } \\
\text { Akademik,Keuangan dan Prodi } \\
\text { 3. Pelayanan sesuai dengan standar operasional kampus. } \\
\text { 1. Peningkatan kualitas dosen dan pelayanan prima } \\
\text { dilakukan terus menerus } \\
\text { 2. Perbaikan fasilitas sarana dan prasarana secara terus } \\
\text { menerus } \\
\text { 3. Kurikulum revolusioner sesuai dengan kebutuhan dan } \\
\text { kemajuan pasar. }\end{array}$ & $1,2,3$ \\
\hline
\end{tabular}

Analisis Statistik Deskriptif

Analisis statistik deskriptif dalam penelitian kuantitatif, dilakukan untuk menjawab pertanyaan masalah yang mengarah kepada gambaran variabel yang diteliti, sehingga karakteristik yang dimiliki oleh data tersebut dan gambaranempiris tentang variabel yang diteliti dapat dipahami.Ukuran yang termasuk dalam teknik analisis statistik deskriptif adalah distribusi frekuensi, ukurantendensi sentral, dan ukuran dispersi.

\section{Analisis Korelasi}

Analisis korelasi digunakan untuk mengetahui derajat hubungan linear antara satu variabel dengan variabel lain. Suatu variabel dikatakan memiliki hubungan dengan variabel lain jika perubahan suatu variabel memiliki korelasi positif. Sebaliknya, jika perubahannya berlawanan arah, kedua variabel tersebut memiliki korelasi negatif. Jika perubahan variabel tidak diikuti oleh perubahan variabel yang lain maka dikatakn bahwa variabel-variabel tersebut tidak saling berkorelasi (Suliyanto; 2011:15)
Korelasi Product Moment (Pearson)

Korelasi product moment atau pearson digunakan untuk mengetahui hubungan antar variabel jika data yang digunakan memiliki skala interval atau rasio. Untuk mencari koefisien korelasi Product Moment digunakan rumus sebagai berikut :

$$
r_{x y}=\frac{n \sum X Y-\left(\sum X\right)\left(\sum Y\right)}{\sqrt{\left\{n \sum X^{2}-\left(\sum X\right)^{2}\right\} \sqrt{\left\{n \sum Y^{2}-\left(\sum Y\right)^{2}\right\}}}}
$$

\section{Dimana:}

$\mathrm{r}_{\mathrm{xy}}=$ Koefisien Korelasi Product Moment

$\mathrm{n}=$ Jumlah Pengamatan

$\sum \mathrm{X}=$ Jumlah dari pengamatan nilai $\mathrm{X}$

$\sum \mathrm{Y}=$ Jumlah dari pengamatan nilai $\mathrm{Y}$

$\mathrm{r}_{\mathrm{xy}}$ merupakan koefisien korelasi yang

nilainya akan senantiasa berkisar antara -1 sampai dengan 1. Bila koefisien korelasi semakin mendekati angka satu berarti korelasi tersebut semakin kuat, tetapi jika koefisien korelasi tersebut mendekati angka 0 berati korelasi tersebut lemah.

Tabel 2. Kriteria Koefisien Korelasi

\begin{tabular}{|l|l|}
\hline Nilai r & Kriteria \\
\hline 0,00 s/d 0,29 & Sangat lemah \\
0,30 s/d 0,49 & Lemah \\
0,50 s/d 0,69 & Cukup \\
0,70 s/d 0,79 & Kuat \\
0,80 s/d 1,00 & Sangat Kuat \\
\hline
\end{tabular}




\section{Uji Persyaratan Analisis}

Sebelum dilakukan analisis dengan regresi, dilakukan uji persyaratan analisis terlebih dahulu. Uji persyaratan analisis, meliputi:

\section{Uji Normalitas.}

Uji normalitas data untuk mengetahui normal atau tidaknya suatu data.Uji ini sebenarnya untuk menentukan apakah distribusi dua populasi mempunyai bentuk yang serupa atau tidak (Nazir, 1999:486).Namun dalam beberapa aspek, uji ini juga digunakan untuk menentukan normalitas data (Sya'ban, 2005:24). Uji normalitas data dapat dilihat pada hasil Kolmogorov-Smirnov dan juga Asymp. Sig. (Signifikan pada taraf 2 tail), maka untuk mengetahui normal tidaknya suatu data dapat dilihat dari hasil Asymp. Sig. (2 tailed) dengan taraf signifikansi $5 \%(0,05)$. Jika hasil sig. tersebut lebih besar dari 0,05 , maka distribusi dua titik normal $(\mathrm{p}<0,05)$. Adapun hasil signifikansi untuk Asymp. Sig. (2 tailed) semuanya lebih besar dari 0,05 maka distribusi data telah normal.

\section{Uji Multikolinieritas}

Multikolinieritas adalah kondisi adanya hubungan linier di antara beberapa atau semua variabel independen. Dampak adanya multikolinieritas dalam estimasi menggunakan metode least square (Widarjono, 2005) adalah:

1) Estimator masih BLUE tetapi mempunyai varian dan covarians yang besar,sehingga sulit mendapatkan estimasi yang tepat.

2) Akibat dari poin 1, selang kepercayaan cenderung lebih lebar dan nilai hitung statistik uji t akan kecil sehingga membuat variabel bebas secara statistik tidak signifikan memengaruhi variabel tak bebas.

3) Nilai koefisien determinasi (R2) masih relatif tinggi, tetapi uji parsial tidak signifikan.

Pengujian multikolinieritas dapat menggunakan nilai VIF (Variance Inflation Factor).VIF mengukur seberapa besar varians dari penduga parameter meningkat besarnya dibandingkan dengan jika variabel bebasnya tidak saling berkorelasi.Nilai VIF yang besar (>5) mengindikasikan adanya multikolinearitas.

\section{Uji Heterokedastisitas}

Uji heteroskedastisitas digunakan untuk mengetahui ada atau tidaknya penyimpangan asumsi klasik heteroskedastisitas yaitu adanya ketidaksamaan varian dari residual untuk semua pengamatan pada model regresi.Prasyarat yang harus terpenuhi dalam model regresi adalah tidak adanya gejala heteroskedastisitas. Ada beberapa metode pengujian yang bisa digunakan diantaranya yaitu Uji Park, Uji Glesjer, Melihat pola grafik regresi, dan uji koefisien korelasi Spearman.

Metode uji Park yaitu dengan meregresikan nilai residual $\left(\mathrm{Lnei}^{2}\right)$ dengan masing-masing variabel dependen $\left(\mathrm{LnX}_{1}\right.$ dan $\operatorname{LnX}_{2}$ ).

Kriteria pengujian adalah sebagai berikut:

1. $\mathrm{H}_{0}$ : tidak ada gejala heteroskedastisitas

2. $\mathrm{H}_{1}$ : ada gejala heteroskedastisitas

3. $\mathrm{H}_{0}$ diterima bila $-\mathrm{t}$ tabel $<\mathrm{t}$ hitung $<\mathrm{t}$ tabel berarti tidak terdapat heteroskedastisitas dan $\mathrm{H}_{0}$ ditolak bila $\mathrm{t}$ hitung $>\mathrm{t}$ tabel atau - $\mathrm{t}$ hitung < - $\mathrm{t}$ tabel yang berarti terdapat heteroskedastisitas.

\section{Koefisien Determinasi $\left(R^{2}\right)$}

Uji $R^{2}$ digunakan untuk mengukur kebaikan atau kesesuaian suatu model persamaan regeresi. Besaran $\mathrm{R}^{2}$ dihitung dengan rumus :

$$
\begin{gathered}
\frac{\sum\left(\tilde{Y}_{i}-\tilde{Y}\right)^{2}}{\sum\left(\tilde{Y}_{i}-\tilde{Y}\right)^{2}}=\frac{S S E}{S S T}=1-\frac{S S R}{S S T} \\
\mathrm{R}^{2}=\frac{\text { Dan adjusted } \mathrm{R}^{2} \text { dihitung dengan }}{\text { Dan }}
\end{gathered}
$$
rumus :

$$
\bar{R}^{2}=1-\frac{\left(1-R^{2}\right)(n T-1)}{n T-n-k}
$$

Dimana :

SSE : jumlah kuadrat yang dijelaskan

SSR : jumlah kuadrat residual

$\mathrm{n}$ : jumlah individu 
Suparman, Pengaruh Strategi Pemasaran Dan Pelayanan Perguruan Tinggi Terhadap Kepuasan... intersep

$\mathrm{T} \quad$ : jumlah periode

$\mathrm{k} \quad$ : banyaknya variabel bebas tanpa

Uji koefisien regresi secara simultan (uji F)

Uji $F$ digunakan untuk mengetahui apakah variabel bebas secara bersama-sama signifikan mempengaruhi variabel independen. Hipotesis pengujiannya :

$\mathrm{H}_{0}: \beta_{1}=\beta_{2}=\ldots=\beta_{\mathrm{k}}=0$

$\mathrm{H}_{1}$ : paling sedikit salah satu nilai $\beta_{\mathrm{p}} \neq$ 0 , dengan $\mathrm{p}=1,2, . . \mathrm{k}$

Statistik uji $\mathrm{F}$ dihitung dengan formula sebagai berikut :

$$
\mathrm{F}_{(\mathrm{k}-1, \mathrm{nT}-\mathrm{n}-\mathrm{k})}=\frac{\frac{R 2}{k-1}}{\frac{1-R^{2}}{n T-n-k}}
$$

$\mathrm{R}^{2}$ adalah koefisien determinasi pada model terpilih, $\mathrm{k}$ adalah jumlah parameter tanpa intersep, $\mathrm{n}$ adalah jumlah individu, dan $\mathrm{T}$ adalah jumlah periode waktu. Hipotesis nul ditolak jika $F_{\text {hitung }}>F_{\alpha}$; (k-1, NT-N-k) yang berarti bahwa minimal ada satu variabel bebas yang signifikan berpengaruh terhadap variabel independen. Keputusan ini dapat juga didasarkan pada perbandingan nilai $p$-value dengan taraf nyata $(\alpha)$.Hipotesis nul ditolak jika nilai $\mathrm{p}$-value lebih kecil dari taraf nyata $(\alpha)$.

\section{Uji koefisien regresi secara parsial (uji t)}

Uji $t$ digunakan untuk mengetahui apakah varabel bebas secara parsial berpengaruh signifikan terhadap variabel tak bebasnya. Hipotesis pengujiannya :

$$
\begin{aligned}
& \mathrm{H}_{0}: \beta_{\mathrm{p}}=0 \\
& \mathrm{H}_{1}: \beta_{\mathrm{p}} \neq 0
\end{aligned}
$$

Statistik uji yang digunakan adalah statistik uji t. Adapun formulanya adalah :

$$
\mathrm{t}_{\text {hitung }}=\frac{\tilde{\beta}_{p}}{\operatorname{se} \tilde{\beta}_{p}}
$$

$\hat{\beta}_{p}$ adalah nilai penduga parameter ke-p, se $\beta_{p}$ adalah simpangan dari nilai penduga parameter ke-p. Hipotesis nul ditolak jika $\left|t_{\text {hitung }}\right|>\mathrm{t}$ a/2 ; (nT-n-k). Keputusan ini dapat juga didasarkan pada perbandingan nilai $p$ value dengan taraf nyata $(\alpha)$.Hipotesis nul ditolak jika nilai $p$-value lebih kecil dari taraf nyata $(\alpha)$.Hal ini berarti secara parsial variabel bebas ke-p signifikan memengaruhi variabel tidak bebasnya dengan tingkat kepercayaan sebesar $(1-\alpha)$ x 100 persen.

\section{Lokasi dan Jadwal Penelitian}

Lokasi penelitian ini di laksanakan di Sekolah Tinggi Ilmu Administrasi Mandala Indonesia (STIAMI) Jakarta kampus Pusat Program Sarjana. Jadwal penelitian ini berlangsung dari Maret 2013 hingga Januari 2014.

\section{Hasil Penelitian Dan Pembahasan}

\section{Gambaran Umum Objek Penelitian \\ Sekolah Tinggi Ilmu Administrasi Mandala Indonesia (STIAMI)}

Sekolah Tinggi Ilmu Administrasi Mandala Indonesia didirikan pada tanggal 27 Januari 1983 oleh dosen dosen senior FISIP UI. STIAMI memperoleh status Terdaftar pada tahun 1989, status Diakui pada tahun 1993. Dan pada tahun 1998 STIAMI berstatus AKREDITASI B. Pada tahun 2000 STIAMI menyelenggarakan jenjang Program Diploma III dan pada tahun 2003 STIAMI memperoleh status dengan peringkat "AKREDITASI A" untuk jenjang SARJANA Program Studi (S1) ILMU ADMINSITRASI PUBLIK dan "AKREDITASI A" untuk Program Studi (S1) ILMU ADMINISTRASI BISNIS. Pada tahun 2005 STIAMI kembali membuka jenjang Program Pascasarjana Magister Ilmu Administrasi (S2/M.Si) dan pada tahun 2010 STIAMI kembali mempertahankan status "AKREDITASI A" untuk Program Studi (S1) ILMU ADMINISTRASI BISNIS dan Program Studi (S1) ILMU ADMINISTRASI PUBLIK berstatus TERAKREDITASI. Kemudian pada tahun 2012, STIAMI mendapatkan Sertifikasi ISO 9001: 5152 2008 untuk Sistem Manajemen Mutu dari QS Certification Zurich Swiss, dan kedepan STIAMI berupaya dapat mengembangkan program pendidikan sampai ke Stata 3 (S3/Doktor).

\section{Program Unggulan Strata I}

\section{Dasar Kebijakan}


Program Kelas Pajak Unggulan adalah

1) Program yang seluruh mahasiswanya akan ditempatkan bekerja di Perusahaan Swasta setelah menyelesaikan studi dan menjadi sarjana perpajakan dengan perjanjian tertulis di awal antara orang tua siswa dan pihak kampus STIAMI;

2) Program yang kurikulum dan metode pembelajarannya disusun secara sistematis, kompetitif, dan unik sehingga memiliki nilai lebih bagi penggunanya.

\section{Tujuan dan Sasaran}

Mencetak intelektual profesional yang bermoral dan beretika yang memiliki kemampuan dan keterampilan di bidang perpajakan (nasional maupun internasional) dengan kemampuan dalam:

1) Melaksanakan kewajiban Perpajakan Pajak Penghasilan WP Orang Pribadi dan badan;

2) Melaksanakan kewajiban Perpajakan Pajak Pertambahan Nilai;

3) Melaksanakan kewajiban Kepabeanan (Custom Clearance);

4) Berkomunikasi dan berkorespondensi dalam bahasa Inggris;

5) Mengajukan keberatan kepada fiskus dan banding kepada pengadilan pajak;

6) Memahami peraturan perpajakan negaranegara ASEAN dan menganalisisnya;

7) Memahami dan menguasai peraturan perpajakan Eropa, khususnya negaranegara maju;

8) Melakukan Tax Planning dan menyelenggarakan manajemen perpajakan;

9) Mendampingi Wajib Pajak dalam proses pemeriksaan dan penyidikan pajak;

10) Melaksanakan kewajiban perpajakan Wajib Pajak untuk Pajak Daerah

11) Memahami proses penagihan pajak yang dilakukan fiskus;

12) memahami konsep-konsep manajemen appraisal dan mempraktekannya.

\section{Peserta}

Program Kelas Pajak Unggulan diperuntukkan bagi siswa SMA/SMK/MA yang lulus Tes Seleksi Masuk tertulis dan wawancara yang diselenggarakan oleh STIA Mandala Indonesia.

\section{Persyaratan Mahasiswa}

a) Lulus tes seleksi masuk program kelas pajak unggulan (baik tes tertulis maupun wawancara)

b) Telah menandatangani surat perjanjian tertulis dengan STIAMI mengenai jaminan penempatan kerja

c) Mahasiswa wajib mematuhi dan menjalankan segala program dan kebijakan yang dikeluarkan STIAMI untuk Kelas Pajak Unggulan.

(1) Bersedia mengikuti perkuliahan sesuai dengan jadwal yang telah ditentukan;

(2) Bersedia mengikuti evaluasi kelas pajak unggulan yang diselenggarakan pada akhir semester 2, 4, dan 6 .

(3) Bersedia mengikuti program-program up grade yang ditentukan STIA Mandala Indonesia

d) Pemberlakuan sistem gugur bagi mahasiswa yang tidak kapabel untuk melanjutkan program kelas pajak unggulan (Sistem gugur dijalankan sesuai hasil evaluasi proses belajar mahasiswa yang dilakukan secara periodik, yaitu setiap satu tahun sekali. Mahasiswa yang tidak memenuhi standar evaluasi harus menerima konsekuensi berupa pemindahan PBM ke kelas regular atau DO)

\section{Persyaratan Dosen}

a) Dosen yang mengajar adalah dosen-dosen akademisi senior, dan praktisi (dengan mempertimbangkan kemampuan dan penguasaan materi dan metode pembelajaran).

b) Kualifikasi dosen akademisi senior: minimal berpendidikan S2 dan memiliki jabatan akademik minimal lektor. Kualifikasi dosen praktisi: berpengalaman sebagai praktisi minimal $5-10$ tahun di bidangnya serta memiliki pengalaman mengajar minimal selama 5 tahun.

c) Dosen PA selain berfungsi untuk bimbingan akademik juga harus menjalankan fungsi sebagai evaluator 
proses belajar mahasiswa dan motivator (minimal sebulan sekali mengadakan pertemuan dengan catatan perkembangan mahasiswa yang jelas).

\section{HASIL PENELITIAN}

\section{Uji Validitas dan Indikator Valid}

Secara keseluruhan hasil uji validitas terhadap butir-butir pernyataan dalam variabel Pemasaran adalah valid, begitupula dengan butir-butir pernyataan variabel kualitas pelayanan dan kepuasan pelanggan seluruhnya adalah valid.

Tabel 3. Hasil Uji Validitas Variabel Pemasaran

Pemasaran

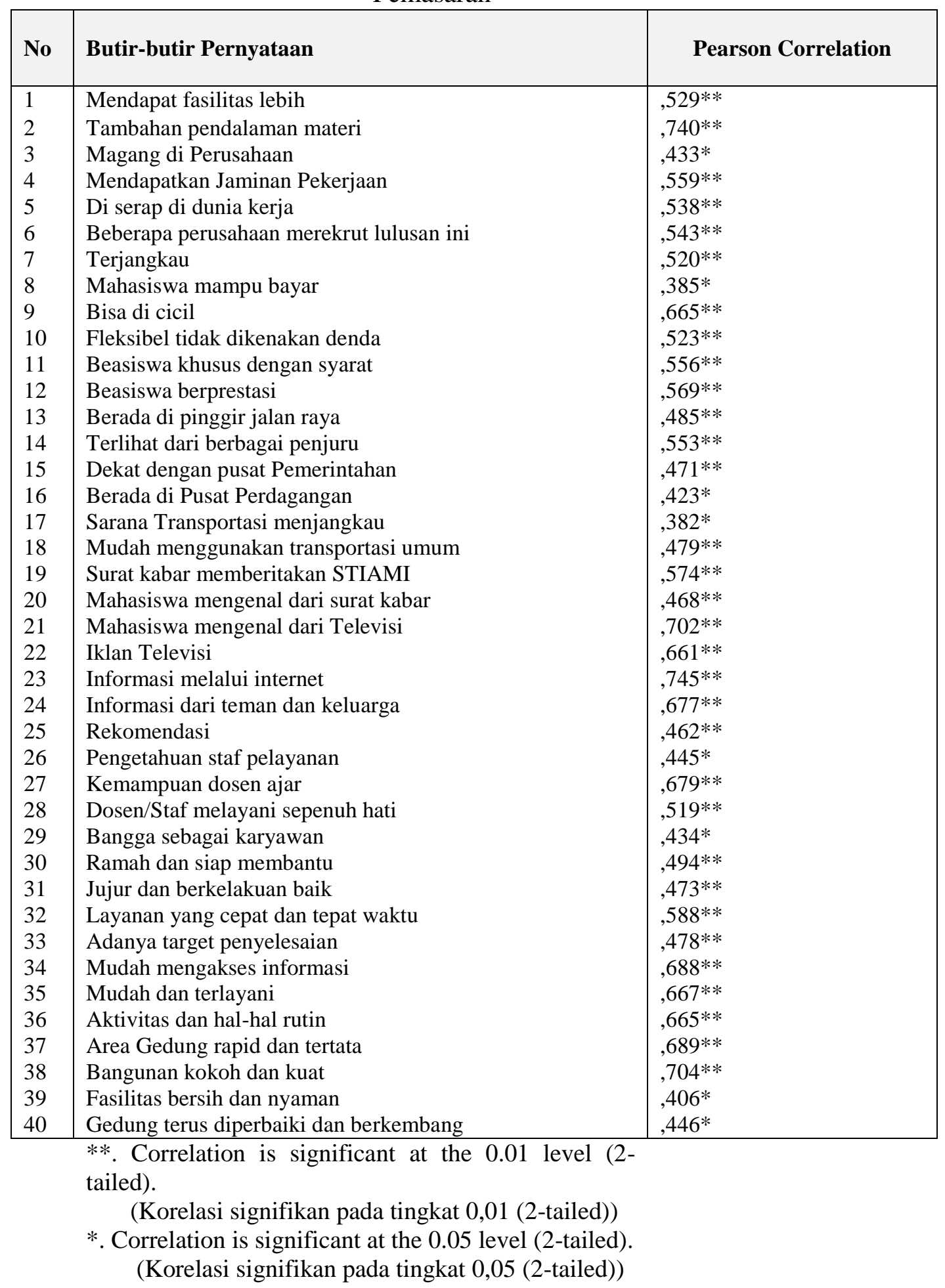




\section{ISSN 1411-0830}

Berdasarkan butir pernyataan yang terbentuk item dinyatakan valid, karena nilai pearson dari variabel pemasaran hasil audit, semua correlation bernilai positif dan $>0,3$

Tabel 4. Hasil Uji Validitas Variabel Kualitas Pelayanan

Kualitas Pelayanan

\begin{tabular}{|l|l|l|}
\hline No & Butir Pernyataan & $\begin{array}{l}\text { Pearson } \\
\text { Correlation }\end{array}$ \\
\hline 1 & Fasilitas kuliah di STIAMI lengkap &, $703^{* *}$ \\
2 & Fasilitas terjaga, kebersihan dan terawat &, $717 * *$ \\
3 & Tersedia Fasilitas Pendukung &, $757 * *$ \\
4 & Staf Berpenampilan Rapi &, $775^{* *}$ \\
5 & Staf selalu sapa santun dan sopan &, $757 * *$ \\
6 & Staf memberikan pelayanan standart &, $777^{* *}$ \\
7 & Sarana lengkap berfungsi dengan baik &, $772^{* *}$ \\
8 & Sarana tersedia dengan baik &, $721^{* *}$ \\
9 & Staf memberikan perhatian penuh kepada Mahasiswa &, $726 * *$ \\
10 & Mahasiswa mudah mengakses, menghubungi staf untuk memperoleh informasi &, $700^{* *}$ \\
11 & Staf memberikan kebutuhan mahasiswa dengan sungguh-sungguh &, $797 * *$ \\
12 & Staf memberi pelayanan dengan dari awal sampai akhir &, $720^{* *}$ \\
13 & Penanganan administrasi data mahasiswa akurat &, $649 * *$ \\
14 & Pelayanan sesuai dengan yang dijanjikan &, $706 * *$ \\
15 & Staf memberikan pelayanan yang cepat kepada mahasiswa &, $773 * *$ \\
16 & Staf dalam membantu kesulitan mahasiswa dengan cepat dan tanggap &, $664 * *$ \\
17 & Staf menanggapi permintaan mahasiswa dengan cepat &, $716^{* *}$ \\
18 & STIAMI telah terakreditasi A &, $564 * *$ \\
19 & Staf memiliki kompetensi dan pelayanan terhadap mahasiswa &, $628^{* *}$ \\
20 & Staf ramah, bersahabat dalam memberikan pelayanan terhadap mahasiswa &, $735 * *$ \\
\hline & $* *$ Correlation is significant at the 0.01 level (2-tailed). & \\
\hline
\end{tabular}

Berdasarkan butir pernyataan yang terbentuk dari variabel kualitas pelayanan semua item dinyatakan valid, karena nilai pearson correlation bernilai positif dan $>0,3$

Tabel 5. Hasil Uji Validitas Variabel Kepuasan Pelanggan

\begin{tabular}{|l|l|l|}
\hline No & Butir Pernyataan & $\begin{array}{l}\text { Pearson } \\
\text { Correlation }\end{array}$ \\
\hline 1 & Pengetahuan yang lengkap dan sempurna dari Dosen &, $494^{* *}$ \\
2 & Kualitas pelayanan yang prima dari Staf Akademik, Keuangan dan Prodi &, $725^{* *}$ \\
3 & Sedikit Komplain &, $501^{* *}$ \\
4 & Sedikit kesalahan yang dilakukan Staf Akademik, Keuangan, Prodi &, $795^{* *}$ \\
5 & Informasi yang lengkap dan akurat dari bagian Akademik, Keuangan dan Prodi &, $846^{* *}$ \\
6 & Pelayanan sesuai dengan standar operasional kampus &, $715^{* *}$ \\
7 & Peningkatan kualitas dosen dan pelayanan prima dilakukan terus menerus &, $556^{* *}$ \\
8 & Perbaikan fasilitas sarana dan prasarana secara terus menerus &, $572^{* *}$ \\
9 & Kurikulum revolusioner sesuai dengan kebutuhan dan kemajuan pasar &, $583^{* *}$ \\
\hline
\end{tabular}


Majalah Ilmiah Institut STIAMI

ISSN 1411-0830

Berdasarkan butir pernyataan yang terbentuk semua item dinyatakan valid, karena nilai dari variabel kepuasan pelanggan hasil audit, pearson correlation bernilai positif dan $>0,3$

\section{a. Uji Reliabilitas}

\section{Tabel 6. Hasil Uji Reliabilitas Variabel Penelitian}

\begin{tabular}{|l|l|l|}
\hline No & Nama Variabel & $\begin{array}{l}\text { Cronbach's } \\
\text { Alpha }\end{array}$ \\
\hline 1 & Pemasaran &, 940 \\
2 & Kualitas Pelayanan &, 951 \\
3 & Kepuasan Pelanggan &, 819 \\
\hline
\end{tabular}

Secara keseluruhan variabel yang digunakan dalam tesis ini adalah reliabel secara statistik karena memiliki nilai Cronbach's Alpha $>0,600$. Hal ini menggambarkan bahwa kuesioner yang digunakan tergolong reliabel untuk mendapatkan informasi yang diperlukan. Variabel pemasaran merupakan variabel dengan nilai Cronbach's Alpha tertinggi, sedangkan kepuasan pelanggan memiliki nilai Cronbach's Alpha terendah.

\section{b. Uji Multikolinearitas}

Dari hasil uji di bawah ini tampak bahwa semua variable bebas tidak berkorelasi satu sama lain karena nilai VIF <10. ; yang menunjukkan bahwa tidak pelanggaran asumsi klasik yaitu semua variabel bebas saling bebas.

Tabel 7. Hasil Uji Multikolinearitas

Coefficients $^{\mathrm{a}}$

\begin{tabular}{|ll|l|l|}
\hline \multirow{2}{*}{ Model } & \multicolumn{3}{|l|}{ Collinearity Statistics } \\
\cline { 3 - 4 } & & Tolerance & VIF \\
\hline 1 & Strategi Pemasaran & 403 & 2,478 \\
& Pelayanan Akademik &, 403 & 2,478 \\
\hline
\end{tabular}

a. Dependent Variable: Kepuasan Mahasiswa

Dari hasil uji multikolinearitas diketahui bahwa nilai Varian Inflation Factor (VIF) menunjukkan tidak ada satu variabel strategi pemasaran pelayanan akademik yang

\section{Uji Heteroskedastisitas.}

Tabel 8. Uji Heteroskedastisitas

Coefficients $^{\mathrm{a}}$

\begin{tabular}{|c|c|c|c|c|c|c|}
\hline \multirow{2}{*}{\multicolumn{2}{|c|}{ Model }} & \multicolumn{2}{|c|}{ Unstandardized Coefficients } & \multirow{2}{*}{\begin{tabular}{|l} 
Standardized \\
Coefficients \\
Beta \\
\end{tabular}} & \multirow[b]{2}{*}{ t } & \multirow[b]{2}{*}{ Sig. } \\
\hline & & B & Std. Error & & & \\
\hline \multirow[t]{3}{*}{1} & (Constant) & 1,135 &, 554 & & 2,049 &, 050 \\
\hline & Strategi Pemasaran &,- 239 &, 309 &,- 224 &,- 776 &, 444 \\
\hline & Pelayanan Akademik &, 110 &, 248 &, 128 &, 443 &, 661 \\
\hline
\end{tabular}

a. Dependent Variable: Abs

Dari hasil Uji Heteroskedastisitas seperti pada Tabel 4.20 diketahui bahwa seluruh variabel memiliki nilai signifikansi > memiliki nilai VIF lebih dari 10. Hal ini menunjukkan bahwa model persamaan regresi tidak terdapat problem multikolinearitas dan dapat digunakan dalam penelitian ini.
0,05, maka dikatakan tidak terjadi heteroskedastisitas, sehingga model regresi layak digunakan untuk memprediksi variabel. 
Majalah Ilmiah Institut STIAMI

ISSN 1411-0830

\section{Uji Normalitas}

Tabel 9. Hasil Uji Normalitas Kolmogorov-Smirnov

One-Sample Kolmogorov-Smirnov Test

\begin{tabular}{|ll|l|l|l|}
\hline & & Strategi & & \\
& & Pemasaran & $\begin{array}{l}\text { Pelayanan } \\
\text { Akademik }\end{array}$ & $\begin{array}{l}\text { Kepuasan } \\
\text { Mahasiswa }\end{array}$ \\
\hline $\mathrm{N}$ & Mean & 2,7672 & 2,8833 & 32 \\
Normal Parametersa,b & Std. Deviation &, 50718 &, 63155 &, 51302 \\
& &, 084 &, 127 &, 118 \\
Most Extreme Differences & Absolute &, 084 &, 117 \\
& Positive &, 084 &, 127 &,- 118 \\
Kolmogorov-Smirnov Z & Negative &,- 080 &,- 102 &, 666 \\
Asymp. Sig. (2-tailed) & &, 475 &, 720 &, 768 \\
\hline
\end{tabular}

Uji Normalitas Kolmogorov - Smirnov terhadap variable penelitian menunjukkan bahwa seluruh variabel penelitian berdistribusi normal karena nilai Sig. > 0,05.

\section{Analisis Korelasi}

\section{Tabel 10. Hasil Uji Analisis Korelasi}

Pearson Correlation
\begin{tabular}{|l|l|l|l|}
\hline No & Nama Variabel & $\begin{array}{l}\text { Kepuasan } \\
\text { Mahasiswa }\end{array}$ & Keterangan \\
\hline 1 & Pemasaran &, 665 & \\
2 & Kualitas Pelayanan &, 858 & \\
& & & \\
\hline
\end{tabular}

Hasil analisis korelasi menunjukkan bahwa

dengan Kepuasan Pelanggan/Mahasiswa variabel Pemasaran memiliki korelasi cukup

\section{Koefisien Determinan}

Tabel 11. Hasil uji Koefisien Determinan

Model Summary ${ }^{\mathrm{b}}$

\begin{tabular}{|c|c|c|c|c|}
\hline Model & $\mathrm{R}$ & R Square & Adjusted R Square & $\begin{array}{l}\text { Std. Error of the } \\
\text { Estimate }\end{array}$ \\
\hline 1 &, $858^{\mathrm{a}}$ &, 736 &, 718 &, 27237 \\
\hline
\end{tabular}

Hasil uji koefisien determinasi diperoleh gambaran besarnya pengaruh variabel Pemasaran dan Kualitas Pelayanan secara bersama-sama terhadap Kualitas Pelanggan/Mahasiswa sebagai mana terlihat pada tabel 4.18 adalah sebesar 0.718 (Adjusted R Squares). Nilai ini menunjukkan bahwa variasi total pengaruh seluruh variabel bebas terhadap variabel Kualitas Pelanggan/Mahasiswa sebagaimana tercantum pada tabel 4.18 dibawah ini sebesar 71,8 persen. Ini berarti pengaruh variabel lain diluar variabel yang diteliti adalah sebesar 28,2 persen. 
ISSN 1411-0830

\section{Uji-f (Uji Simultan)}

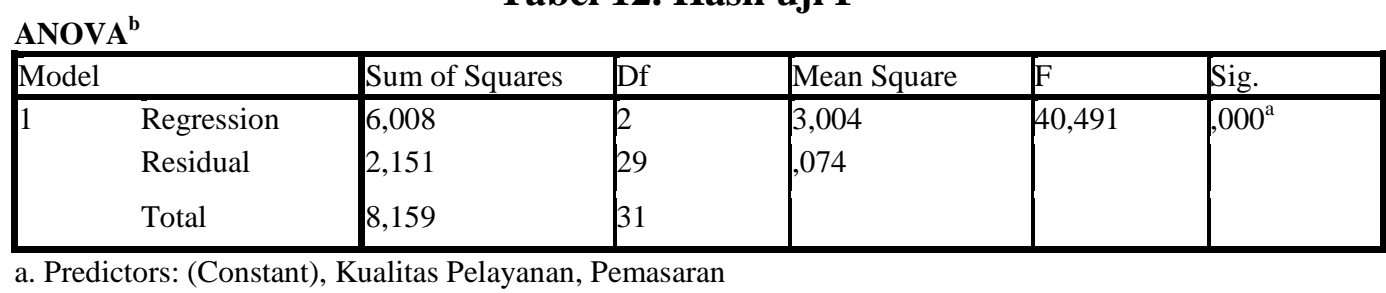

a. Predictors: (Constant), Kualitas Pelayanan, Pemasaran

b. Dependent Variable: Kepuasan Pelanggan

Untuk menguji keberartian model digunakan Uji F seperti tercantum pada tabel 4.19 di bawah ini menunjukkan bahwa model adalah nyata karena diperoleh Signifikansi sebesar $0,000(<0,05)$. Ini berarti $\mathrm{H}_{0}$ diterima atau $\mathrm{H}_{1}$ ditolak , sehingga dapat dikatakan bahwa seluruh variabel bebas mempunyai pengaruh terhadap variabel tidak bebas. Dengan demikian, tujuan penelitian yang kedua dapat dibuktikan bahwa Pemasaran dan Kualitas Pelayanan secara simultan ternyata mempengaruhi Kepuasan Pelanggan.

\section{Uji-t (Uji Parsial)}

uji-t (Uji Parsial) adalah untuk mengetahui pengaruh masing-masing variabel bebas terhadap variabel tidak bebasnya. Suatu variabel bebas dikatakan mempunyai pengaruh terhadap variabel tidak bebas dalam tabel Coefficient ini dapat dilihat dari nilai $\mathrm{t}$ yang dihasilkan dari program SPSS. Kriteria menerima atau menolaknya ditentukan oleh nilai signifikansi (Sign.).

a) Suatu variabel bebas dikatakan signifikan pada tingkat keyakinan 99 persen terhadap variabel tidak bebas jika nilai signifikansinya 0,01 .

b) Suatu variabel bebas dikatakan signifikan pada tingkat keyakinan 95 persen terhadap variabel tidak bebas jika nilai signifikansinya 0,05 .

c) Suatu variabel bebas dikatakan signifikan pada tingkat keyakinan 90 persen terhadap variabel tidak bebas jika nilai signifikansinya 0,10 .

Dalam penelitian ini digunakan penghitungan toleransi kesalahan sebesar 5 persen $(\alpha=0,05)$.

Coefficients $^{\mathrm{a}}$

Tabel 13. Hasil Uji t

\begin{tabular}{|c|c|c|c|c|c|c|}
\hline \multirow{2}{*}{\multicolumn{2}{|c|}{ Model }} & \multicolumn{2}{|c|}{ Unstandardized Coefficients } & \multirow{2}{*}{\begin{tabular}{|l|}
$\begin{array}{l}\text { Standardized } \\
\text { Coefficients }\end{array}$ \\
Beta
\end{tabular}} & & \multirow[b]{2}{*}{ Sig. } \\
\hline & & $\mathrm{B}$ & Std. Error & & t & \\
\hline \multirow[t]{3}{*}{1} & (Constant) & 1,074 &, 273 & & 3,940 &, 000 \\
\hline & Pemasaran & ,.007 &, 152 &, 007 & .044 &, 966 \\
\hline & Kualitas Pelayanan & 693 &, 122 &, 853 & 5,682 &, 000 \\
\hline
\end{tabular}

a. Dependent Variable: Kepuasan Pelanggan

Hasil Uji-t untuk setiap variabel bebas dapat dijelaskan sebagai berikut:

1) Nilai signifikansi pada konstanta pada tabel diatas adalah sebesar 0,000 $(>0,01)$ yang berarti dengan tingkat keyakinan 99 persen konstanta adalah nyata. Nilai koefisien regresi adalah 1,074 yang berarti bahwa jika tidak ada pengaruh Pemasaran dan Kualitas Pelayanan maka Kepuasan Pelanggan adalah 1,074 satuan.
2) Nilai signifikasi pada variabel Pemasaran adalah sebesar $0,966(<0,05)$ yang berarti tidak ada pengaruh variabel Pemasaran secara parsial terhadap Kepuasan Pelanggan.

3) Nilai signifikasi pada variabel Kualitas Pelayanan adalah sebesar $0,000 \quad(<0,01)$ yang berarti dengan tingkat keyakinan 99 persen variabel Kualitas Pelayanan secara parsial sangat nyata mempengaruhi Kepuasan Pelanggan. Besarnya pengaruh 
variabel Kualitas Pelayanan terhadap Kepuasan Pelanggan ditunjukkan oleh nilai koefisien regresinya sebesar 0,693. Ini berarti jika variabel Pemasaran naik satu satuan maka Kepuasan Pelanggan akan meningkat sebesar 0,693satuan, dengan syarat variabel Pemasaran adalah konstan (Ceteris Paribus).

Berdasarkan tabel coefficient diatas, persamaan regresi bergandanya adalah :

$\hat{Y}=1,074+0,007 X_{1}+0,693 X_{2}$

Dari persamaan regresi tersebut diatas, dapat dijelaskan sebagai berikut :

Nilai kostanta sebesar 1,074 artinya jika strategi pemasaran $\left(\mathrm{X}_{1}\right)$, Kualitas Pelayanan $\left(\mathrm{X}_{2}\right)$, bernilai 0 maka menyebabkan Nilai Y meningkat sebesar 1,074 satuan.

Koefisien regresi Strategi Pemasaran $\left(\mathrm{X}_{1}\right)$, sebesar 0,007 artinya jika variabel kualitas pelayanan $\left(\mathrm{X}_{2}\right)$ konstan, maka peningkatan $\left(\mathrm{X}_{1}\right)$ satu satuan akan meningkat (Y) sebesar 1,074 satuan. Koefisien regresi kualitas pelayanan $\left(\mathrm{X}_{2}\right)$, sebesar 0,693 artinya jika variabel strategi pemasaran $\left(\mathrm{X}_{1}\right)$ konstan, maka peningkatan $\left(\mathrm{X}_{2}\right)$, satu satuan akan meningkatkan (Y) sebesar 0,693 satuan.Dengan demikian tujuan penelitian yang pertama dapat dibuktikan bahwa dari kedua variabel bebas hanya Kualitas Pelayanan yang berpengaruh secara parsial terhadap Kepuasan Pelanggan.

\section{PEMBAHASAN}

Berdasarkan analisis di atas telah terjawab kedua tujuan penelitian secara parsial maupun simultan. Secara parsial dari 2 variabel independen hanya Kualitas Pelayanan yang berpengaruh terhadap Kepuasan Pelanggan, jika variabel Kualitas Pelayanan naik satu satuan maka Kepuasan Pelanggan akan meningkat sebesar 0,693 satuan, dengan syarat variabel Pemasaran adalah konstan (Ceteris Paribus).Temuan menarik dalam penelitian ini adalah Pemasaran sebagai variabel utama penelitian ini belum memberikan pengaruh positif terhadap Kepuasan Pelanggan/mahasiswa. maka selanjutnya perlu dibahas eksistensi masing-masing variabel sebagai berikut:

\section{Pengaruh Pemasaran Terhadap Kepuasan Pelanggan STIAMI Jakarta}

Dari Deskripsi Variabel Pemasaran diatas, distribusi jawaban responden terbanyak antara $2,33-2,80$ (37,5 persen) yang berarti menurut responden Strategi Pemasaran di STIAMI cukup memuaskan secara statistik. Variabel pemasaran memiliki 7 sub variabel/dimensi yang terdiri dari product, pricing, place, promotion, people, process, dan physical evidence, menurut pernyataan responden nilai rata-rata terendah adalah dimensi promotion 2,4219 < 3,00 yang berarti Promotion di STIAMI tidak memuaskan secara statistik.

Pengaruh Pelayanan terhadap Kepuasan Pelanggan/ Mahasiswa pada Sekolah Tinggi Ilmu Administrasi Mandala Indonesia (STIAMI).

Kualitas Pelayanan di STIAMI menurut pernyataan responden yang kemudian diolah secara statistik menghasilkan nilai rata-rata sebesar 3,09 dengan standar deviasi 0,89.

Variabel Kualitas Pelayanan memiliki 5 sub variabel/dimensi yang terdiri dari Tangibles, empathy, Reliability, Responsiveness, dan Assurance,menurut pernyataan responden nilai rata-rata terendah adalah dimensi empathy 2,6354 mendekati 3,00 yang berarti empathy di STIAMI cukup memuaskan secara statistik.

Pengaruh Pemasaran dan Kualitas Pelayanan terhadap Kepuasan Mahasiswa pada Sekolah Tinggi Ilmu Administrasi Mandala Indonesia (STIAMI).

Kepuasan Pelanggan yang dalam penelitian ini adalah Mahasiswa STIAMI, menurut pernyataan responden yang kemudian diolah secara statistik menghasilkan nilai rata-rata sebesar 2,97 dengan standar deviasi 0,93. Variabel Kualitas Pelayanan memiliki 3 sub variabel/dimensi yang terdiri dari Tidak ada keluhan, tidak ada kesalahan, dan perbaikan terus menerus menurut pernyataan responden nilai rata-rata terendah adalah dimensi tidak ada kesalahan 2,9792 mendekati 3,00 yang 
Suparman, Pengaruh Strategi Pemasaran Dan Pelayanan Perguruan Tinggi Terhadap Kepuasan...

berarti Dimensi Tidak Ada Kesalahan di STIAMI cukup memuaskan secara statistik.

\section{SIMPULAN}

Berdasarkan hasil penelitian untuk menjawab kedua tujuan penelitian adalah sebagai berikut:

1. Secara parsial strategi pemasaran berpengaruh signifikan terhadap kepuasan Pelanggan/Mahasiswa. Namun temuan menarik dalam penelitian ini yaitu pemasaran belum memberikan kepuasan terhadap pelanggan/ Mahasiswa hal ini dapat dilihat dari hasil penelitian diperoleh nilai rata-rata terendah adalah dimensi promotion $2,4219<3,00$ yang berarti Promotion di STIAMI tidak memuaskan secara statistik.

2. Pelayanan berpengaruh signifikan terhadap kepuasan pelanggan. Berdasarkan hasil penelitian yang dilakukan penulis diperoleh nilai rata-rata terendah adalah dimensi empathy 2,6354 mendekati 3,00 yang berarti empathy di STIAMI cukup memuaskan secara statistik.

3. Berdasarkan hasil analisis diperoleh nilai signifikan product merupakan yang terbesar pengaruhnya terhadap kepuasan Pelanggan/Mahasiswa yaitu sebesar 2,8281 dari variabel pemasaran. Sedangkan assurance merupakan yang terbesar pengaruhnya terhadap kepuasan Pelanggan/Mahasiswa yaitu sebesar 3,1458 . Dengan demikian hipotesis yang menduga bahwa assurance merupakan factor yang paling dominan dari Kualitas Pelayanan (service quality) yang mempengaruhi kepuasan pelanggan terbukti.

\section{SARAN}

Berdasarkan kesimpulan di atas, maka peneliti menyarankan Pemasaran yang terkait dengan Promosi perlu ditingkatkan dan dilakukan inovasi-inovasi agar programprogram yang ditawarkan STIAMI menarik minat calon mahasiswa yang akan menimba ilmu di STIAMI, karena Strategi Pemasaran tujuannya adalah menarik minat anggota masyarakat (calon pelanggan/mahasiswa) untuk menggunakan jasa layanan pendidikan yang diberikan oleh STIAMI.

Disamping itu adanya standard pelayanan yang ditetapkan pihak STIAMI, agar memiliki gret atau standarisasi sesuai dengan Corporate Culture STIAMI. Ini akan memiliki pengaruh besar terhadap kepuasan Pelanggan/Mahasiswa khususnya dalam pelayanan, sehingga menumbuhkan rasa nyaman dan kepuasan terhadap informasi yang didapatkan.

\section{DAFTAR PUSTAKA}

Ainswort, Murray, Neville Smith, and Anne Millership, 2002. Managing Performance Managing People: Understanding and Improving Team Performance. Printed in Australia by Griffin Press.

Djaslim saladin, 2007 manajemen pemasaran, printile hall.

Gregirius Chandra, 2002 strategi dan program pemasaran, Andi Yogyakarta.

Kotler Philip, 2004 manajemen Pemasaran edisi millennium, PT. Prenhallindo Jakarta.

Mulyana. E, 2003. Kurikulum Berbasis Kompetensi, Remaja Rosda Karya.

Nasution, M.N, 2004. Manajemen Jasa Terpadu, Jakarta: Ghalia Indonesia.

Neuman, Lawrens W 2006. Social Research Method, Qualitative and Quantitative Approaches. Six Edition. Boston New York, London: Pearson Education Inc.

Nur'aeni, 2011. Pengaruh Motivasi, Kompetensi Dan Komitmen Terhadap Kinerja Dosen Pada Perguruan Tinggi Swasta Di Lingkungan

Oliver, Richard L, 1997, Satisfaction A Behavioral Respective on The Customer, Mc Graw-Hill, Companies In, Singapore.

Panji, Anggoro, 2005. Analisis Faktor-Faktor kualitas Pelayanan Yang Mempengaruhi Kepuasan Mahasiswa Pada Perguruan Tinggi "AUB" Surakarta.

Parasuraman, Valerie A. Z and Berry. 1990, Delivering Quality Service, McMilan. Hal 15. 
ISSN 1411-0830

Pedoman Penulisan Tesis Dan Artikel Ilmiah Program Pascasarjana Ilmu Administrasi, 2012. Sekolah Tinggi Ilmu Administrasi Mandala Indonesia Jakarta.

Peraturan Pemerintah Republik Indonesia Nomor: 19 Tahun 2005 tentang Standar Nasional Pendidikan. Dediknas RI. Jakarta.

Sukmono, Rita Ambarwati Analisa Pengaruh Bauran Pemasaran dan Kualitas Layanan terhadap Loyalitas Pelangan dengan Metode Structural Equation Modeling (studi kasus : bni cabang tanjung perak Surabaya).2011.

Tampubolon, 2001. Manajemen Pendidikan, Jakarta.

Tjiptono, Fandy. 1996, Manajemen Jasa, Penerbit, Andi Yogyakarta.

William J. Stanton, 1989 prinsip pemasaran edisi ke tujuh jilid 1, erlangga.

Yamin, H. Martinis, 2009. Profesionalisasi Guru Dan Implementasi KTSP
Rangkuti, Freddy. 2002. Measuring Customer Satisfaction. Gramedia Pustaka Utama.

Santosa, Purbayu Budi dan Ashari, 2005, Analisis . Statistik Dengan Microsoft Excell \& SPSS, Andi Offset.

Sugiyono. 2009. Metode Penelitian Bisnis. Penerbit CV. Alpabeta. Bandung

dilengkapi UU No. 14 Tahun 2005 Tentang Guru Dan Dosen, Gaung Persada Press. GP press.

Zeithaml, Valerie; A.A. Pasuraman, and Leonard L. Berny. 2009. Delivering Quality Servive; Balancing Customer Perceptions and Expectations. New York; The Free Press.

Zeithaml, Valerie A and Bitner, Mary Jo. 2003. Service Marketing. McGraw Hill Inc, Edition, New York. 